\title{
Drug Use and the Spread of HIV/AIDS in South America and the Caribbean
}

\author{
FRANCISCO INÁCIO BASTOS, ${ }^{1}$ STEFFANIE A. STRATHDEE, \\ MONICA DERRICO ${ }^{1} \&$ MARIA DE FÁTIMA PINA ${ }^{1}$ \\ ${ }^{1}$ Department of Health Information (DIS/CICT), Oswaldo Cruz Foundation, UNAIDS \\ Collaborative Centre, Biblioteca de Manguinhos, suite 209, Av. Brasil, 4365 21045-900 Rio de \\ Janeiro, Brazil; ${ }^{2}$ Infectious Diseases Program, School of Hygiene and Public Health, \\ Department of Epidemiology, Johns Hopkins University, Baltimore, MD, USA
}

ABSTRACT We review available data on drug use with respect to the spread of HIV/AIDS in South America and the Caribbean. Although many information gaps remain, the emerging picture clearly shows the significant role of both injected cocaine and crack cocaine in the Brazilian epidemic, and the increasingly large role of injecting cocaine in the Southern Cone. The Caribbean and the Andean regions are thus far spared from extensive diffusion of injecting drugs and its consequences. However, these regions are now experiencing a significant transition, in terms of an increasing role of crack cocaine in the Caribbean HIV/AIDS epidemic, and the recent introduction of heroin and initiation of drug injection in the Andean region. Harm-reduction strategies are being implemented for the first time in recent years after a long delay, but remain primarily restricted to Brazil, and to a lesser extent, Argentina. Yet even in these settings, harm-reduction programmes such as needle-exchange programmes face considerable challenges with respect to restrictive legislation and lack of broader support.

\section{Introduction}

Since the beginning of the HIV/AIDS epidemic, AIDS cases have been reported among persons in North America and Europe who injected drugs. In South America and the Caribbean, the first AIDS case among an injecting drug user (IDU) was reported in the city of São Paulo, Brazil, in 1983 (Grangeiro, 1994). Early in the epidemic, it was recognized that needle sharing constituted an important risk factor for HIV infection (Des Jarlais et al., 1985). More recent studies point to potential additional risks posed by shared use of injection paraphernalia (e.g. cookers, cotton, water) (Jose et al., 1993; Koester et al., 1996), and possibly the drug preparations themselves (Strathdee et al., 1998b).

South America and the Caribbean represent regions deeply affected by the HIV / AIDS epidemic, but the extent to which IDUs and crack users, their sexual partners and offspring are affected varies greatly within and between countries. In this review, we highlight salient features of the HIV/AIDS epidemic among drug users in South America and the Caribbean. We also describe recent efforts to implement harm-reduction programmes in regions where there has been considerable diffusion of injection drug use and HIV. 


\section{Methods}

As a first step, we reviewed standard medical and social science databases (e.g. Medline, AIDSline), using as key words the terms HIV/AIDS, drug use, and Latin or South America and the Caribbean. As a second step, we assessed additional databases targeting literature available only in Portuguese or Spanish, or non-indexed major databases (e.g. Lilacs). Next, abstract books and/or electronic databases (CD-ROMs) for recent conferences (e.g. 12th International Conference on AIDS; 9th International Conference on the Reduction of Drug Related Harm) were thoroughly examined. All available regional conference proceedings (published primarily in Portuguese and Spanish) were also assessed, as well as data obtained from personal contacts with the members of the Latin American harm-reduction network, non-governmental organizations (NGOs), and health authorities from different countries. Below, we summarize the findings obtained from these sources.

\section{Overview on Drug Use and HIV/AIDS}

Patterns of HIV spread among IDUs are affected by the metamorphosis of local and international drug scenes, as well as social norms surrounding needle sharing and sexual behaviours. The rapid and often catastrophic spread of HIV among IDUs has led to greater visibility and legitimacy of this hidden population, although in virtually every country, injection drug use continues to be highly stigmatized. Until recently, IDUs were seldom targeted by public health interventions in the developing world (Wodak et al., 1993). This was the case despite the fact that IDUs continue to be at high risk of acquiring other serious blood-borne infections (i.e. Hepatitis B, C, D and G, HTLV-I/II and malaria; Des Jarlais et al., 1996; Garfein et al., 1996).

Injection of illicit psychoactive drugs and the spread of HIV/AIDS among IDUs affect a large number of countries, both in the developed and developing world. Of 126 countries reporting injection drug use in 1997, 98 have detected HIV among IDUs (Strathdee et al., 1998b). Regions with extensive spread of HIV among IDUs include south-eastern Asia, the north-eastern USA, southern Europe, the former Soviet Republic, and the Southern Cone of Latin America (Bastos et al., 1998a; Strathdee et al., 1998b). Very recently, alterations in drug use patterns have been observed in regions that had thus far been spared by the diffusion of 'western' patterns of drug consumption, including the use of illicit injecting drugs. For example, injection drug use is becoming more common in parts of sub-Saharan Africa which function as a trans-shipment route for heroin, cocaine and other illicit drugs (Adelekan \& Stimson, 1997). These observations illustrate the extent to which diffusion of HIV / AIDS and other blood-borne infections among IDUs have become a true global challenge.

Although most studies carried out earlier in the epidemic addressed the transmission of HIV among heroin injectors, other patterns of injecting psychoactive drugs (e.g. amphetamines, cocaine) (Anthony et al., 1991; Klee, 1992) have been clearly linked to HIV transmission. Higher HIV transmission risks among cocaine injectors are probably due to the pattern of frequent injection of this drug and its close relationship to the sex trade (Anthony et al., 1991; Edlin et al., 1994). High HIV seroprevalence rates have been observed in regions where 
cocaine is the sole or principal injected drug, both in the developing countries (Carvalho et al., 1996; Telles et al., 1997) and, to some extent in developed countries (Anthony et al., 1991; Bruneau et al., 1997; Strathdee et al., 1997b).

A key factor in the role of IDUs in HIV spread, apart from the size of these populations and their background seroprevalence levels, is the extent to which they mix with other drug users and the general population (Montoya \& Atkinson, 1996). Mixing between a sizable population of HIV-infected IDUs, crack cocaine users and the general population can shape regional HIV/AIDS epidemics. Epidemics with basically assortative mixing patterns (like-with-like) tend to follow different epidemic waves (i.e. separate epidemics among persons with high and low risks) relative to disassortative (like-with-unlike) mixing patterns, which tend to generate epidemics with a greater impact and spread (Gupta et al., 1989). Locations or situations which promote efficient mixing (e.g. shooting galleries, prisons), may create extensive transmission chains which have undoubtedly contributed to the establishment of IDU-associated HIV epidemics locally and worldwide (Des Jarlais \& Friedman, 1993; Taylor et al., 1995).

In a world undergoing a rapid process of globalization, drug scenes often experience turmoil that fosters high risk behaviours, and subsequent increases in the risk of HIV transmission. Developing countries function as raw commodities, producing transit routes of drug distribution and money laundering (Adelekan \& Stimson, 1997; Arbex Jr. \& Tognolli, 1996). Individuals and peer groups also undergo transitions throughout their drug-using careers (Des Jarlais et al., 1992; Strang et al., 1992). Recruitment of new injectors into the drug scene (Friedman et al., 1998) and recidivism to injecting among ex-IDUs (van Ameijden et al., 1994) are two examples that reflect the dynamic pattern of drug use and HIV risk which needs to be considered in the planning of prevention programmes.

\section{Regional Patterns of Drug Consumption and Major Trends in AIDS Cases Among Drug Users in South America and the Caribbean}

The AIDS epidemic in South America and the Caribbean is quite heterogeneous, as displayed in Figure 1 and Table 1.

In countries like Paraguay (Southern Cone), Bolivia (Andean area) and most of the Caribbean, the role of IDUs in the HIV/AIDS epidemic is very restricted. The few AIDS cases registered in this exposure category have frequently had contacts abroad. On the other hand, the AIDS epidemic has spread extensively in some highly populated countries (e.g. Brazil), and in some small countries like Haiti, the Baham as and French Guiana. The role of IDUs and crack users in these regions is quite different, as shown in Tables 1 and 2. In countries where diffusion of injection drug use has been extensive (e.g. Brazil and Argentina), there are clear regional patterns. In other countries where consumption of drugs through injection remains uncommon, HIV transmission occurs predominantly through sexual transmission.

In many Caribbean countries, use of illicit drugs (e.g. crack and powder cocaine) is frequently linked to HIV spread through unprotected sexual intercourse and the sex trade. Many studies have addressed the influence of psychoactive substances, especially crack, upon risky sexual behaviour, and HIV infection or other sexually transmitted infections (STIs) (Seidman et al., 1994; Shafer et al., 1993). The intense craving for drugs often leads crack cocaine users to engage in commercial sex, which creates a dynamic mixing pattern between 
Table 1. Proportional number of AIDS cases among IDUs (\%) vis-à-vis total number of registered AIDS cases, in selected countries of South America and the Caribbean (including different proportional numbers for IDUs in different time periods, once available, 1995-97)

\begin{tabular}{|c|c|c|c|c|}
\hline Region & Country & $\%$ & Year ${ }^{a}$ & Reference \\
\hline \multirow[t]{7}{*}{ Southern Cone } & \multirow[t]{2}{*}{ Chile } & 0.03 & (1994) & Yáñez et al., 1995 \\
\hline & & 6.0 & (1997) & Teixeira, 1997 \\
\hline & \multirow[t]{2}{*}{ Paraguay } & 10.0 & (1994) & Jiménez, 1995 \\
\hline & & 11.0 & (1997) & Teixeira, 1997 \\
\hline & Argentina & 41.3 & (1995) & Betts et al., 1996 \\
\hline & \multirow[t]{2}{*}{ Uruguay } & 25.0 & (1996) & Berriolo et al., 1997 \\
\hline & & 33.0 & (1997) & Teixeira, 1997 \\
\hline Brazil & Brazil & 20.6 & (1997) & Fonseca \& Castilho, 1997 \\
\hline \multirow{3}{*}{$\begin{array}{l}\text { Central America and } \\
\text { the Caribbean }\end{array}$} & Cuba & 0.0 & (1994) & Peña et al., 1995 \\
\hline & Haiti & $<1.0$ & (1994) & Hyppolite \& Pape, 1995 \\
\hline & Puerto Rico (USA) & $>50.0$ & (1995) & Colón et al., 1996 \\
\hline
\end{tabular}

Sources: See references for full detail.

a 'Year' refers to the last year from which data were drawn in the reference (not the year of paper publication). In the few cases in which publication/presentation year is the same as the last revised data upon which analyses were based, one must remark that data for the 'last year' never include all cases reported for the full year.

crack users and IDUs, the latter which often have high background HIV seroprevalence rates (Montoya \& Atkinson, 1996).

\section{The Caribbean}

The Caribbean has been for decades a traditional trans-shipment route for cocaine from Andean coca-producing countries to the markets of North America and Europe. Since the 1970s and 1980s the Caribbean drug scene was renowned for widespread cultivation and consumption of cannabis, and incidental use of cocaine. However, by the end of the 1980s and thereafter, crack cocaine became popular in many Caribbean islands, such as the French Caribbean (CharlesNicholas, 1997) and the Bahamas (Gomez et al., 1996). Similar increases in cocaine consumption (e.g. by smoking and/or snorting) appear to be occurring in Central America (Low et al., 1993).

According to the literature and anecdotal reports, injection of cocaine is still very uncommon throughout the Caribbean, and presently has no meaningful role in the dynamic of the HIV/AIDS sub-epidemics taking place in this region. However, the role of crack cocaine and its close relationship to the sex trade has contributed to the spread of HIV through heterosexual transmission (Gomez et al., 1996), as has been shown in the USA (Edlin et al., 1994). The extent to which crack users mix with non-drug users in the region or with tourists is not well documented. Such data are needed to inform prevention and policy.

Although located in the same geographical space, Puerto Rico has a radically distinct drug scene. The conspicuous presence of injected cocaine is strongly associated with the local HIV/AIDS epidemic (Colón et al., 1996). Due to its unique socio-economic situation and cultural background, and its close ties to the USA, its regional pattern of IDU-associated HIV infections is more similar to 


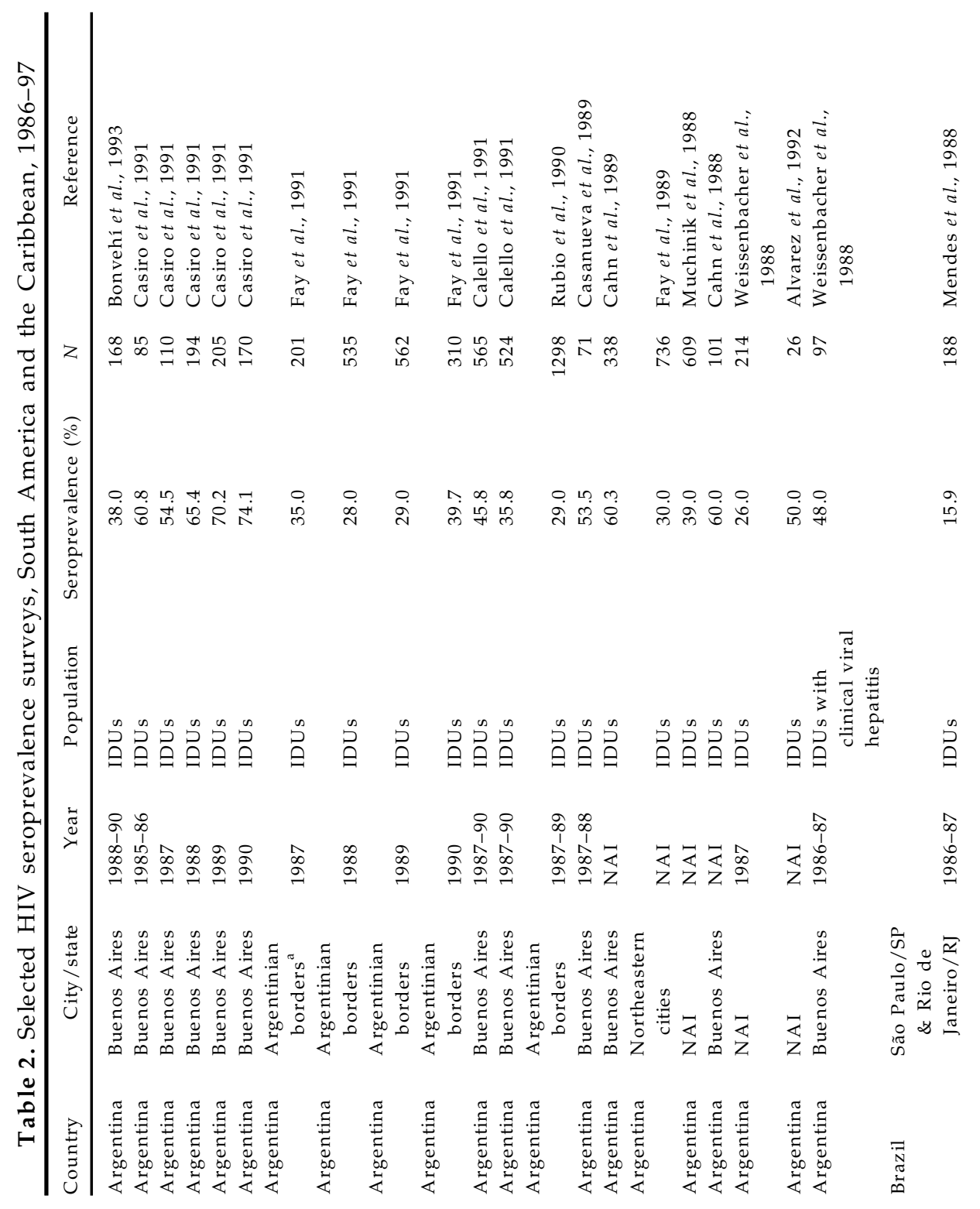




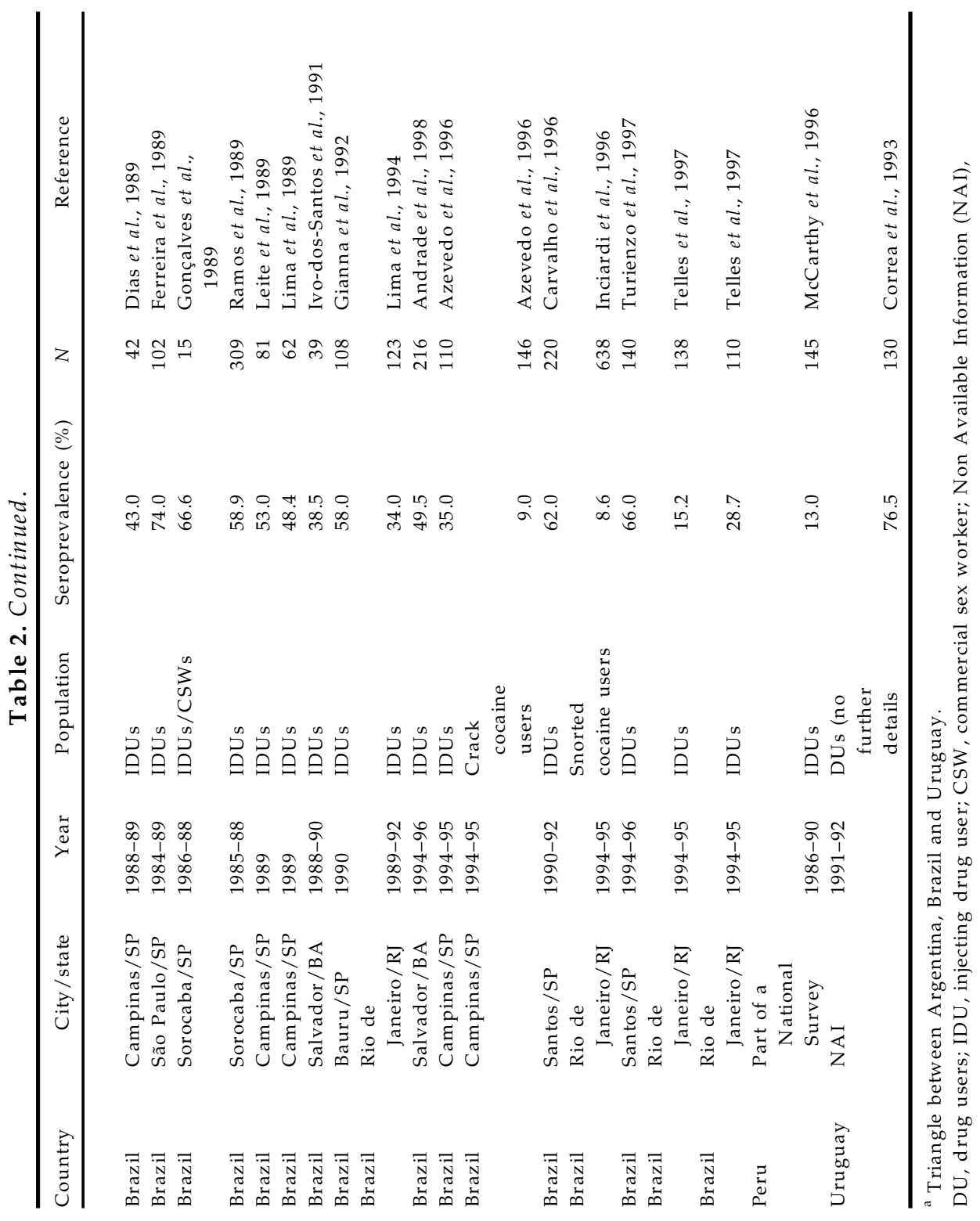




\section{AIDS Accumulated Incidence Rates among South American \& Caribbean Countries 1982-1995 \\ (Except Puerto Rico)}

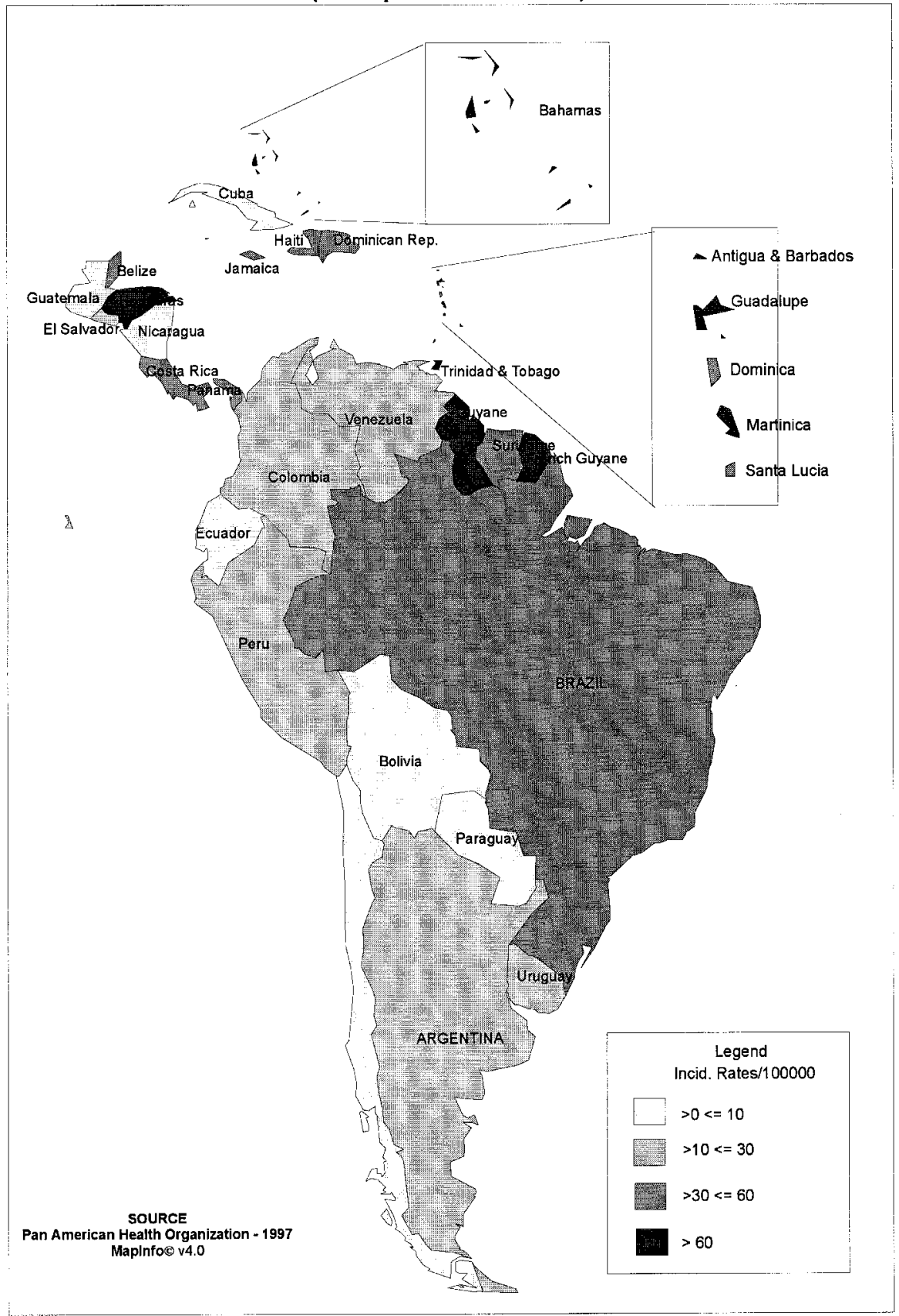

Figure 1. AIDS accumulated incidence rates among South American and Caribbean countries, 1982-95 (except Puerto Rico). 
continental USA than South America or the Caribbean. For these reasons, its specific characteristics will not be addressed in the present paper.

\section{Brazil}

Previous studies (Barcellos \& Bastos, 1996; Bastos \& Barcellos, 1995; Szw arcwald \& Bastos, 1998) have shown that Brazil, due to its continental size and strong social and cultural heterogeneity, harbours many different HIV sub-epidemics (Szwarcwald et al., 1998b). IDUs have thus far had a negligible role in the AIDS epidemic in the less industrialized areas located in north-eastern Brazil, with an exception being the State of Bahia, which is the southern-most state in this region. However, IDUs have played a central role in the HIV/AIDS subepidemic in the industrialized south-east, especially in São Paulo State, and the south coastal line extending from São Paulo to the south border of Brazil (Figure 2).

The IDU-associated HIV/AIDS epidemic in Brazil roughly follows the main cocaine trans-shipment routes, from the western border to the coastal main ports located in the south-east (Barcellos \& Bastos, 1996). A similar phenomenon was described for heroin routes in Asia (Berkley, 1993). The trans-shipment cocaine routes-linking the west and the south-east of the country-benefit from the best Brazilian highway network (see Figure 2), with many small collateral roads, essential to the transportation of agro-industrial goods and people trying to evade the police. The specific use of these highways may promote diffusion of injection drug use and with it, spread of blood-borne pathogens.

International research indicates that IDUs are a very mobile population (WHO International Collaborative Group, 1994), which often has a dramatic impact on the spread of blood-borne pathogens. A unique example is the occurrence of two outbreaks of secondary malaria among IDUs in São Paulo State that had been free of malaria for decades. These outbreaks were attributed to migration of IDUs from other areas in the country where malaria was endemic (Bastos et al., 1995). Since most of these IDUs were also co-infected with HIV, this example illustrates how diffusion of blood-borne pathogens can occur even in remote areas. This presents a challenge for prevention that has yet to be addressed in virtually every country that reports injection drug use.

More recently in Brazil, HIV has spread to smaller ports on the south coast, probably due to new drug smuggling strategies and/or the expansion of drug-consuming markets in southern middle-sized coastal cities. Cities in these regions now report that over $50 \%$ of all AIDS cases are among IDUs. For example, Itajaí and Balneário de Camboriú, both in the State of Santa Catarina, rank among cities with the highest AIDS incidence rates in Brazil (Bastos, 1996a).

In contrast to recent increases in AIDS incidence rates among southern cities, municipalities like Santos (SP) (the biggest Brazilian port) experienced a high HIV / AIDS burden in the beginning of the epidemic, but have observed a slight decline in new IDU-associated AIDS cases over the past 5 years. This suggests that Brazil is experiencing chronologically different epidemics. A mature epidemic exists in Santos, where HIV prevalence among IDUs appears to have stabilized at $60 \%$ (Carvalho et al., 1996). However, a more recent epidemic threatens the southern cities and has yet to level off. Recent studies (Szwarcwald \& Bastos, 1998; Szwarcwald et al., 1998b), confirm that diffusion of HIV among IDUs in the State of São Paulo is following a localized growth pattern, 


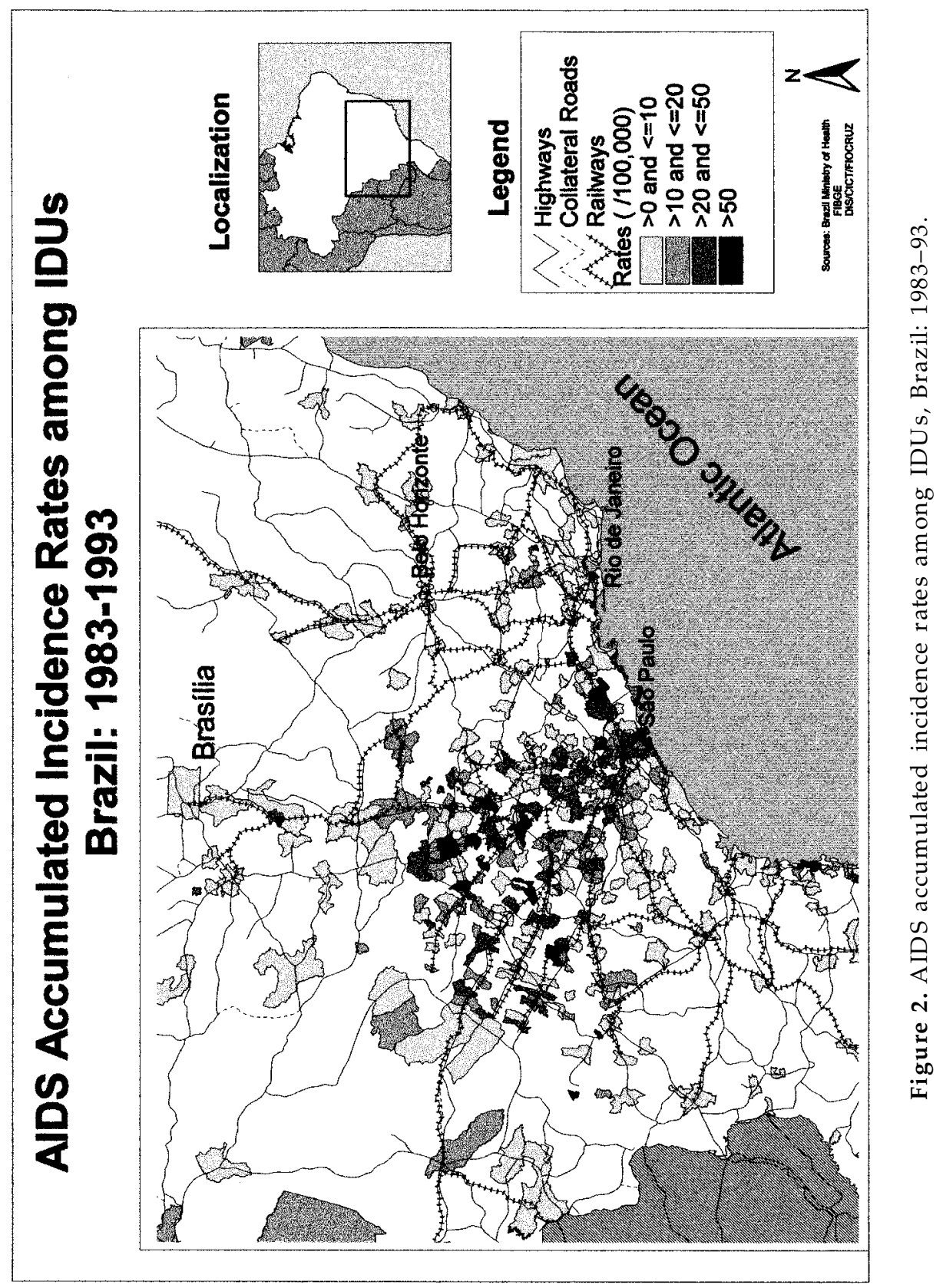


and suggest that the very rapid diffusion of HIV among IDUs, especially at the end of the 1980s, was subsequently overtaken by a large secondary spread of heterosexually acquired infections.

A thorough understanding of the role of injection drug use in specific HIV epidemics must consider local habits and mores, apart from individual behaviours. As shown by Kalichman (1993), Grangeiro (1994) and Fonseca \& Castilho (1997), IDUs are concentrated in the richest socio-economic regions of Brazil, but the vast majority belong to the poorer, less educated strata of Brazilian society. IDUs live mainly in the impoverished surrounding belts of Brazil's richest cities, e.g. São Paulo (Grangeiro, 1994). Prevention programmes also need to take into account that many IDUs interviewed in Rio de Janeiro never buy cocaine, but instead barter sexual services or goods in exchange (Bastos, 1996b). In some regions (e.g. São Paulo), the growing influence of crack and its reliance on the sex trade adds yet another layer of complexity.

Rio de Janeiro, the second largest Brazilian city and port, has a lively drug scene where cocaine is typically snorted. Interestingly, its HIV/AIDS epidemic has not been strongly influenced by its comparatively smaller population of IDUs. As reviewed recently by Telles et al., (1997), HIV seroprevalence rates among IDUs in Rio are high by international standards (i.e. approximately $25 \%$ ), but have not reached the catastrophic level observed in Santos, described earlier. Over the years, AIDS cases attributed to IDU have comprised no more than $7 \%$ of the total AIDS cases reported in Rio de Janeiro. Although Rio shares a geographic proximity to Santos along with many other cultural characteristics (e.g. a large port, a role in trans-shipment of cocaine and a flourishing tourist industry), it has had quite a different drug scene and a distinct HIV/AIDS epidemic among its proportionally smaller population of IDUs.

A previous review of HIV/AIDS epidemiology in Brazil (Bastos et al., 1995) showed that HIV seroprevalence levels are invariably higher among IDUs (Table 2) and a few other at-risk populations (e.g. male transsexuals involved in commercial sex). The diversity in HIV prevalence rates is consistent with the aforementioned heterogeneity of Brazilian epidemic, reflecting a composite of rather diverse regional sub-epidemics and socio-economic strata.

As seen in Table 2, several studies indicate persistently high levels of HIV infection among Brazilian IDUs, and to a lesser extent among Brazilian crack users. Since HIV infection rates among the latter group are higher than those among proxies for the general population (e.g. blood donors, pregnant women and army conscripts) (Bastos et al., 1995), the role of crack in the HIV epidemic in Brazil should not be considered negligible.

The contemporary Brazilian drug scene is under a fast-paced transition, consisting of traditional patterns of drug consumption (e.g. cannabis products), over-the-counter psychopharmacological drugs, inhaled substances (e.g. glue) and illicit drugs prevalent in western countries (e.g. powder and crack cocaine) (Bastos \& Carlini-Cotrim, 1998; Bastos et al., 1998a). Regions like Bahia state, which were spared most of the medical consequences of illicit drug use until the 1980s, experienced extensive spread of both HIV and HTLV-I/II in the 1990s (Andrade et al., 1998).

A number of research initiatives in Brazil are focusing on the combined effect of poly-drug use upon HIV risk behaviours. In particular, studies are targeting socially deprived commercial sex workers (Szwarcwald et al., 1998c), users of both crack and injected cocaine (Bastos et al., 1998b) and street youth (Raffaelli 
et al., 1993). Instead of trying to establish linear causal relationships between patterns of drug abuse and risk behaviours, this research aims to consider broad lifestyle patterns (Des Jarlais, 1998), and the interplay between social vulnerability factors, individual behaviours and social networks (Friedman, 1993).

\section{The Southern Cone}

Of all countries in South America and the Caribbean, the Southern Cone has reported the largest number of AIDS cases among IDUs, together with Brazil (Table 1 and 2). Injection drug use accounts for $29 \%$ of all reported AIDS cases in the Southern Cone (Teixeira, 1997). The role of IDUs in Argentina's HIV/ AIDS epidemic has been continuously increasing (Betts et al., 1996), now following a pattern similar to south European countries, where IDU is the most important exposure category (Hamers et al., 1997). The Argentinian IDU sub-epidemic appears to be chronologically delayed relative to Brazil. For instance, the first AIDS case among an IDU was reported in 1983 in Brazil (Grangeiro, 1994), but not until 1985 in Argentina (Inchaurraga, 1997). Unlike Brazil, where the proportion of AIDS cases attributable to IDUs reached a plateau of $21 \%$ in the beginning of the 1990s, the proportion of IDUs among AIDS cases is still increasing in Argentina, from $10 \%$ of the total number of AIDS cases in 1987, to $23 \%$ in $1989,40 \%$ in 1991 and $44 \%$ in 1993.

HIV seroprevalence rates for Argentina (Table 2), the only other South American country where several studies have been carried out, point to a vigorous diffusion of HIV among IDUs. Although caution must be exercised when drawing inferences from these studies, there appears to be a trend towards continuous HIV spread among Argentinian IDUs in recent years.

In Argentina (López, 1997), as well as Brazil (Fonseca \& Castilho, 1997; Grangeiro, 1994), IDUs have had a central role in the impoverishment of the AIDS epidemic. In contrast to earlier years, where persons of higher socioeconomic status were over-represented among AIDS cases, most newly reported AIDS cases are among people living in poor neighbourhoods, who have less education and higher unemployment levels. A similar shift seems to be taking place in Mexico, but thus far IDUs appear to have had a relatively minor role in the spread of HIV/AIDS. Anedoctal reports suggest that the number of IDUs in Mexico is increasing, mainly along the northern US border (Valdespino-Gómez et al., 1995).

In Uruguay and Paraguay, the HIV/AIDS epidemic among IDUs broadly follows Argentina's pattern, but in both countries (especially Paraguay) it follows a protracted course compared to Argentina and Brazil. For instance, AIDS cases registered among Paraguay's IDUs account for $10 \%$ of the total reported AIDS cases, a level that had been reached in Argentina 8 years earlier (Jiménez, 1995). The scope of HIV diffusion among IDUs in Uruguay and Paraguay is more restricted, likely due to the smaller size of their high-risk IDU populations and much fewer numbers of inhabitants. Although Paraguay has a much smaller injecting drug scene, its role as a trans-shipment route seems to be increasing, along with the number of heavy and/or poly-drug users (Míguez et al., 1992). In both countries, the current drug scene combines 'traditional' patterns of drug use, e.g. over-the-counter psychopharmacological drugs, cannabis products and inhalants, with the relatively new habits of injecting cocaine and smoking crack (Berriolo et al., 1997; Míguez et al., 1992). 
The number of AIDS cases among IDUs in Uruguay, in absolute and proportionate terms, has been increasing since the first case $w$ as registered in 1989. The main drugs injected in Uruguay, as well in the other countries of the Southern Cone, are cocaine and amphetamines. A disquieting fact is that reported levels of needle sharing are high in Uruguay. In a survey of 216 IDUs carried out in $1995 / 96,43 \%$ reported ever sharing needles, and the average age of initiation of use was 10-14 years old (Berriolo et al., 1997).

In all countries of the Southern Cone, reported AIDS cases among IDUs are heavily concentrated in the capitals and main metropolitan centres. The pattern formerly described for Brazil of a broad spread of HIV / AIDS among IDUs along middle-size and even smaller cities has not yet been observed in the Southern Cone. However, the extent and variety of sero-surveys carried out among IDUs in those countries is far more limited than in Brazil (Table 2). Due to the impact of the free trade zone (Mercosul), there is increasing commerce and mobilization of the general population and IDUs between and within countries in the Southern Cone and Brazil. In light of the data presented, it can be expected that the role of IDUs in the spread of HIV in Argentina, southern and south-eastern Brazil, Uruguay, Paraguay and Chile, will increase.

\section{The Andean Area}

The availability of coca and its various derivatives (e.g. cocaine powder, coca paste) is not the only factor determining its use. As observed for the different regions of Brazil (Telles \& Bastos, 1995), cocaine 'scenes' tend to be distinct from one another, since they represent a combination of many different derivatives and consumption habits. For example, bazuco (coca base with marijuana and other chemicals) and raw smokable coca paste are largely consumed in centralwest Brazil, but not in south-eastern cities, in what seems to be a dynamic balance between demand and supply.

In the Andean area, powder cocaine is largely available but injection is rare. In Peru, comprehensive surveys have found less than 150 active IDUs among a sample of 141,000 individuals (McCarthy et al., 1996). In Andean countries, the traditional habit of chewing coca leaf has co-existed, especially after the 1980s, with the smoking of raw coca paste and bazuco (mostly by the socially disadvantaged strata) and the snorting of powder cocaine (among middle-class and upper social strata). However, there is a clear predominance of the former in the countryside and the latter in the larger cities (Negrete, 1981).

More recent trends in Colombia include a decline of smokable coca paste, and an increase in the availability of heroin and powder cocaine. This is believed to be due in part to the renewed strategies of drug cartels, which serve to increase the availability of low-quality water-soluble drugs for lower prices (Miguez et al., 1997; Pérez-Gómez, 1996). After 12 years (1983-1995) with no AIDS cases reported among IDUs in Colombia, 33 new cases of AIDS were registered in this exposure category by the Bogota Health Department by November 1997 (Miguez et al., 1997).

\section{Broad Trends in Drug Use in South America and the Caribbean}

Two overarching trends appear to be taking place in South America and the Caribbean: (i) the recent spread of crack cocaine and; (ii) the emergence of opium 
derivatives (e.g. heroin), both as a new crop cultivated by drug cartels (Miguez et al., 1997; Pérez-Gomez, 1996), and as new commodities seeking renewed trans-shipping routes. In some cases, there are new consumption markets occurring along those routes.

Apart from its established role in the Caribbean, it seems clear that crack cocaine will have a prominent role in many regional HIV/AIDS epidemics in South America. Crack has infiltrated countries and regions with distinct socialdemographic and cultural characteristics (e.g. the Bahamas) (Gomez et al., 1996) and south-eastern Brazil (Bastos \& Carlini-Cotrim, 1998). Recent analyse s carried out in Santos, São Paulo and Rio de Janeiro, respectively, have shown that crack smoking is a core risk factor for HIV infection among commercial sex workers (CSWs) in Santos. Crack smoking CSWs also have significantly higher levels of HIV infection compared to non-crack smokers (Szwarcwald et al., 1998c). In a sample of IDUs in Rio de Janeiro, crack smoking IDUs engaged more frequently in risky sexual behaviours than non-crack smoking IDUs (Bastos et al., 1998b). It is also notew orthy that in the USA, crack is sometimes dissolved and injected by IDUs when it provides a cheaper alternative to powder cocaine (Johnson \& Ouellet, 1996). Very recent ethnographic studies have reported the same habit in different Brazilian regions (Minayo et al., 1998).

The role of heroin and the extent of its diffusion in South America have been hotly debated, since strategies of growing and selling heroin-either for the local markets or for exportation-are still quite a recent phenomenon. Most data about the local consumption of heroin in different regions of South America and the Caribbean are basically anecdoctal. Preliminary data show its use is increasing among poly-drug injectors in different areas of Brazil, as disclosed in a recent Brazilian multi-centre study (Bastos \& Carlini-Cotrim, 1998). The first reports of heroin addicts in Brazil, which were identified in the city of São Paulo, indicate that while there were already strong ties to the international market, its presence fell far short of having created a heroin 'street scene' (Laranjeira et al., 1997). Further study of heroin use is clearly required, especially in the city of São Paulo, in order to gain a better understanding of patterns of use.

In the Andean area, availability of heroin is increasing, mainly due to the recent diversification of commodities and crops by drug cartels. The consequences upon local patterns of consumption seem to have been restricted until now (Miguez et al., 1997; Pérez-Gomez, 1996). Future trends are difficult to predict, but its impact could be to increase considerably the diffusion of both injection drug use and blood-borne infections.

The interplay of macro- and micro-social forces, drug consumption patterns and HIV diffusion is complex. Multi-level analyses of these phenomena are virtually lacking in the region. A recent study evaluated broad relationships between social inequalities (i.e. unemployment and housing shortage), and the spread of HIV among drug users in Argentina (López, 1997). Ecological studies carried out in Brazil (Barcellos \& Bastos, 1996; Bastos \& Barcellos, 1995), point to the role of cocaine-trafficking routes and the transit of people and goods through Brazilian municipality networks in the spread of HIV. One must keep in mind that this interplay of forces combines broad macro-social primary determinants with the 'side effects' of drug policies, which were intended to address the very problems they frequently aggravate. For instance, an unintended effect of drug paraphernalia laws, is to often promote risky injecting practices instead of reducing them (Scheerer \& Vogt, 1989). 
Recent studies (Strathdee et al., 1997a, 1997b; Wallace, 1993) have shown that meso-level social factors (e.g. unstable housing) and social network disruption (Wallace, 1993) are associated with risk behaviours and HIV spread in poor neighbourhoods. Very recent analyses in Brazil (Szwarcwald et al., 1998a) have shown that a variety of health and social problems, including HIV spread and homicides, are not only associated with broad social inequalities in the city of Rio de Janeiro, but also with micro-social interactions among social networks in the slums. For example, evidence of social network dissolution and deaths are known to be secondary to local and international drug wars. Further research is required to understand the impact of these factors on HIV transmission patterns.

Two methodological approaches can be used to overcome difficulties in drawing inferences from different levels of aggregation (Susser, 1994). When qualitative methodologies are used, methods to triangulate data and information obtained from different sources have been proposed (Stimson, 1995). In the field of epidemiology and mathematical modelling, hierarchical multivariate models can take into account the different levels of aggregated data (Victora et al., 1997).

\section{The Fate of Preventive Strategies in South America and the Caribbean}

Until very recently, in most South American and Caribbean countries, implementation of harm-reduction strategies has been uneven, and indeed was rarely proposed or discussed. Until the mid-1990s, only a few NGOs and self-help organizations were involved in the development of prevention activities among IDUs, apart from activities which strictly promoted abstinence. Even today, harm-reduction-oriented philosophies are basically restricted to Brazil and Argentina.

The struggle for the implementation of a comprehensive set of harm-reduction initiatives directed at IDUs received a boost in Brazil only after 1992, when the Federal Government requested financial and technical support from the World Bank for AIDS prevention. Analysis of epidemiological data in the beginning of the 1990s made clear to both the World Bank staff and to the Brazilian Health authorities the need to highlight the central role of programmes specifically directed to IDUs and their partners in halting the spread of the epidemic (Bastos et al., 1998a). The process of introducing harm-reduction policies in South America and the Caribbean has been erratic, being influenced by strong opposition from local conservative forces, and the ongoing challenge of cultural and religious prejudices towards most of the core components for reducing harm (e.g. condom distribution) (Bastos, 1996b; Bastos et al., 1998a).

However, the most entrenched barriers in the region seem to be the explicit or implicit legal prohibition to carry out these activities (Bastos, 1996b; Bastos et al., 1998a; Marques \& Doneda, 1998). An additional barrier is the strong influence of rather contradictory international pressure, especially from the USA, to reduce the supply of cocaine in countries that are inherently politically and economically unstable. These political and economical pressures and constraints are particularly vigorous in coca-producing countries, where alternative strategies to strictly enforce supply reduction are difficult to implement (Argañarás, 1997).

Due to its prominent social-economic role in South America and the size of its HIV / AIDS epidemic, the reformulation of Brazilian HIV/AIDS prevention policies has had a significant impact upon activities in most of South America, and to a lesser extent upon countries in the Caribbean. In 1996, for the first time, all 
American countries proposed a common strategy to fight against illicit drug trafficking and consumption in the Americas in a forum sponsored by the Pan American Health Organization, held in Montevideo, Uruguay. Apart from the traditional supply-reduction strategies and law enforcement, this included the implementation of demand-reduction strategies focusing on education and prevention (Berriolo et al., 1997).

In South America, Brazil now has undeniably a key role in the development of harm-reduction strategies. This includes several projects carried out in its many different regions that are supported by a consortium involving the Brazilian Ministry of Health, the World Bank and UNDCP (Marques \& Doneda, 1998). In addition, Argentina is now beginning to implement comprehensive programmes beyond exclusive promotion of traditional abstinence-oriented approaches (Inchaurraga, 1997).

Some initiatives commonly proposed as part of a harm-reduction strategy continue to conflict with national legislations. These include increasing the availability of clean needles and syringes through needle-exchange programmes (NEPs), vending machines and over-the-counter sales (e.g. pharmacies). However, no doubt remains that harm-reduction strategies are being discussed more openly and in fact have been successfully implemented in some countries in South America and the Caribbean.

Apart from NEP, other initiatives being implemented in different countries include increased availability of HIV testing and counselling facilities, and the opening of new drug treatment programmes in countries like Argentina and Brazil (Inchaurraga, 1997; Marques \& Doneda, 1998). In regions where the role of heroin and other opiates has been negligible, innovative substitution therapies for cocaine addiction have been used. For example, in Peru and Bolivia, coca leaf infusion has been used in the treatment of cocaine addiction (Llosa, 1994).

Other core strategies which may indirectly lower HIV infection rates include systematic diagnosis and treatment of major sexually transmitted infections (STIs) (Institute of Medicine, 1997), and free access to highly active anti-retroviral therapy (HAART) for HIV-infected persons. Although the latter is available only in Brazil, these programmes could have a favourable influence on the HIV epidemic in the region, by reducing incidence of STIs which are co-factors for HIV transmission, as well as potentially reducing HIV viral load among infected individuals. However, formal evaluation of such programmes is required. For example, problems have been encountered in the counselling and referral for treatment of STIs in the region (Giffin \& Lowndes, 1998). International literature suggests that adherence to antiretroviral therapies is problematic for IDU populations (Strathdee et al., 1998a).

Despite these positive steps, most prevention initiatives are largely underfunded and the only NEPs which currently exist in South America are located in Brazil (Table 3). To date, most NEPs have opened only recently and are rather small and understaffed, with limited operational capacity. These programmes operate amidst the ongoing threat of having their activities interrupted due to conflicts with national drug legislation and local police officers. However, they represent a turning point in the implementation of harm-reduction activities in the Continent.

A recent training workshop co-ordinated by PSA/WHO and UNAIDS, involving researchers and activists from most Latin American countries (Guarujá, São Paulo, 22-26 March 1998) indicated clearly that implementation of harm- 
Table 3. Needle-exchange programmes (NEPs) in operation in Brazil, as of May, 1998

\begin{tabular}{lllll}
\hline Macro-region & \multicolumn{1}{c}{ State } & \multicolumn{1}{c}{ City } & NEPs $^{\mathrm{a}}$ & Opening date \\
\hline \multirow{2}{*}{ South-eastern } & São Paulo & São Paulo & 2 & $1^{\mathrm{b}}$ \\
& São Paulo & Santos & 2 & $1^{\mathrm{b}} \mathbf{1 9 9 3}^{\mathrm{c}}$ \\
& São Paulo & São Vicente & 1 & 1995 \\
& São Paulo & Sorocaba & 1 & 1996 \\
& São Paulo & S. J. do Rio Preto & 1 & 1996 \\
South & Rio de Janeiro & Rio de Janeiro & 1 & 1996 \\
& Rio Grande do Sul & Porto Alegre & 1 & 1996 \\
North-east & Santa Catarina & Itajaí & 1 & 1995 \\
Centre-west & Bahia & Salvador & 1 & $1995^{\mathrm{d}}$ \\
\hline
\end{tabular}

Source: Minayo et al., (1998).

${ }^{a}$ Number of different NEPs in the city, i.e. co-ordinated by different groups/institutions.

${ }^{b}$ Functioning as an underground NEP in the first years.

${ }^{c}$ Does not include former (aborted) attempts-only very recently have problems with local authorities been solved as needle-exchange is no longer an underground activity.

d First 'open air' NEP in Brazil.

reduction strategies in South America and the Caribbean receive varying levels of political commitment. In a few Latin American countries harm-reduction strategies have received political and community support, and funding. On the other hand, in many others there is a clear prejudice against such programmes by the general public and/or government bodies.

Although we have not highlighted regions that have more direct contact with the USA (e.g. northern border of Mexico, Puerto Rico), these regions have sometimes benefited from a transfer of knowledge with respect to harm-reduction activities. For example, in Puerto Rico there are various outreach programmes with counselling, skills development and condom distribution (Robles et al., 1998). However, the distribution and/or exchange of needles and syringes remains as controversial in these countries as in the USA itself. To date, there are no NEPs in Mexico and Puerto Rico. In the Caribbean, preventive strategies implemented to date primarily address sexual risks and include education and condom distribution (Gomez et al., 1996). In these countries, additional education programmes that discourage transitions to injection are needed.

The dynamic aspects of drug production, commerce and consumption suggest that surveillance must go beyond studies of HIV prevalence and behaviours to anticipate and prevent transitions to injection and accompanying high-risk behaviours. Through sentinel surveillance, communities and institutions can deal with epidemics in their initial stages, and avoid facing high background HIV seroprevalence and efficient mixing patterns among IDUs and the general population which are already established in mature epidemics. Only with accurate data about local patterns of drug consumption and the broad cultural and social-demographic context will it be possible to implement culturally appropriate interventions and evaluate them with respect to their efficacy, timing and cost-benefit relationship. 


\section{Acknowledgements}

This work was partially supported by the Brazilian Ministry of Health and United Nations International Drug Control Programme (UNDCP). F.I.B. and M.D. are, respectively, recipients of National Research Council (CNPq) salary grant (IIB) and a research assistant scholarship.

\section{References}

Adelekan, M. \& Stimson, G. (1997). Problems and prospects of implementing harm reduction for HIV and injecting drug use in high risk sub-saharan African countries. Journal of Drug Issues, 27, pp. 97-116.

Andrade, T., Dourado, I. \& Galvão-Castro, B. (1998). Associations among HTLV-1, HTLV-II and HIV in injecting drug users in Salvador, Brazil. Journal of Acquired Immune Deficiency Syndromes and Human Retrovirology, 18, pp. 186-187.

Anthony, J.C., Vlahov, D. \& Nelson, K.E. et al., (1991). New evidence on intravenous cocaine use and the risk of infection with Human Immunodeficiency Virus Type 1. American Journal of Epidemiology, 134, pp. 1175-89.

Arbex Jr., J. \& Tognolli, C.J. (1996). O Século do Crime [The Century of Crime]. São Paulo: Boitempo Editorial.

Argañarás, F.G. (1997). Harm reduction at the supply side of the drug war: the case of Bolivia. In P.G. Erickson, D.M. Riley, Y.W. Cheung \& P.A. O'Hare (Eds), Harm Reduction; A New Direction for Drug Policies and Programs. Toronto: Toronto University Press, pp. 99-115.

Azevedo, R.C.S., Manfrinatti, M.B., Silvia, J.A.G. \& Lima, E.S. (1996). Drug users knowledge on AIDS and behavioral changes in Campinas, Brazil. Poster [Tu.C.2492] presented at the XI International Conference on AIDS, Vancouver.

Barcellos, C. \& Bastos, F.I. (1996). Redes sociais e difusão da AIDS no Brasil [Social networks and the diffusion of HIV in Brazil]. Boletín de la Oficina Sanitaria Panamericana,121, pp. 11-24.

Bastos, F.I. (1996a). Difusão do HIV entre usuários de drogas injetáveis (UDIs) como fator determinante de epidemias intensas e extensas no Brasil [Diffusion of HIV among IDUs as a key factor in extensive and escalating HIV/AIDS epidemics in Brazil]. Abstract book, pp. 87-89. III Reunião Especial da SBPC (Ecossistemas Costeiros), Florianópolis (SC).

Bastos, F.I. (1996b). Ruína \& Reconstrução-AIDS e Drogas Injetáveis na Cena Contemporanea [Ruin \& Reconstruction-AIDS and Injecting Drugs in the Contemporary Scene]. Rio de Janeiro: RelumeDumará, ABIA \& IMS-UERJ.

Bastos, F.I. \& Barcellos, C. (1995). A geografia social da AIDS no Brasil [The social geography of AIDS in Brazil]. Revista de Saúde Pública, 29, pp. 52-62.

Bastos, F.I., Telles, P.R., Castilho, E.A. \& Barcellos, C. (1995). A epidemia de Aids no Brasil [The AIDS epidemic in Brazil]. In M.C.S. Minayo (Ed.), Os Muitos Brasis: Saúde e População na Década de 80, (pp. 245-68). São Paulo/Rio de Janeiro: Hucitec \& ABRASCO.

Bastos, F.I. \& CARlini-Cotrim, B. (1998). O consumo de substâncias psicoativas entre os jovens brasileiros: dados, danos \& algumas propostas [The consumption of licit and illicit drugs in Brazil: main findings, associated harms and some propositions in the field of prevention]. In BRAZILIAN National Commission on Population \& Development-CNPD (Ed.), Jovens Acontecendo nas Trilhas das Políticas Públicas (Vol. II, pp. 645-69). Brasília: Comissão Nacional de População e Desenvolvimento.

Bastos, F.I., Stimson, G., Telles, P.R. \& Barcellos, C. (1998a). Cities responding to HiV-1 epidemics among injecting drug users. In G. Stimson; D.C. Des Jarla is \& A. Ball (Eds), Drug Injecting and HIV Infection: global dimensions and local responses, (pp. 149-67). London: UCL Press.

Bastos, F.I., Telles, P.R., Bastos JR., W. \& Strathdee, S.A. (1998b). Higher frequency of commercial sex among crack smokers in a sample of injecting drug users, in Rio de Janeiro, Brazil. Poster [23212] presented at the XII International Conference on AIDS, Geneva.

BerkLEy, S. (1993). AIDS in the developing world: an epidemiologic overview. Clinical Infectious Diseases, 17, pp. S329-36.

Berriolo, R., Osimani, M.L., Serra, M. \& Weissenbacher, M.C. (1997). E1 SidA y su asociación con el uso de drogas en Uruguay [AIDS and its association with drug use in Uruguay]. Revista Médica del Uruguay, 13, pp. 45-53.

Betts, C.D., Astarloa, L. \& Bloch, C. et al., (1996). The changing face of AIDS in Argentina. Journal of the American Medical Association, 276, pp. 94-96. 
Bonvehí, P.E., Gómez-Marín, O. \& Cassetti, I. et al., (1993). HiV infection and associated factors among intravenous drug users in Buenos Aires. Poster (PO-C15-2918) presented at the IX International Conference on AIDS, Berlin.

Bruneau, J., Lamothe, F. \& Franco, E. et al., (1997). High rates of HiV infection among injection drug users participating in needle exchange programs in Montreal: results of a cohort study. American Journal of Epidemiology, 146, pp. 994-1002.

CAhn, P., PÉRez, H. \& CASIRó, A. et al., (1989). HIV-infection among IV drug abusers in Buenos Aires, Argentina. Poster (Th.D.P.46) presented at the V International Conference on AIDS, Montreal.

Calello, M., Libonatti, O. \& BoxacA, M. et al., (1991). Increasing risk of heterosexual HiV-1 spreading due to intravenous drug addiction in Argentina. Poster (W.C.3326) presented at the VII International Conference on AIDS, Florence.

Carvalho, H.B., Mesquita, F. \& Massad, E. et al., (1996). HIV and infections of similar transmission patterns in a drug injectors community of Santos, Brazil. Journal of Acquired Immune Deficiency Syndromes and Human Retrovirology,12, pp. 84-92.

Casanueva, E., Hosokawa, R. \& Boxaca, M. (1989). Infection with HIV and HBV in adolescents logged in Security Institutes of Buenos Aires City, IVDA as a risk factor of infection. Poster (M.D.O. 10) presented at the V International Conference on AIDS, Montreal.

Casiro, A., Perez, H. \& Grinberg, N. et al., (1991). Spontaneous attendance for HiV testing in Buenos Aires: 1985-1990. Poster (M.B.2455) presented at the VII International Conference on AIDS, Florence.

Charles-Nicholas, A. (1997). The drug situation in the Caribbean. Paper presented at the VIII International Conference on the Reduction of Drug Related Harm. Abstract book, p. 68, Paris.

Colón, H.M., Robles, R.R. \& Marrero, C.A. et al., (1996). Behavioral effects of receiving HIV test results among injecting drug users in Puerto Rico. AIDS, 10, pp. 1163-68.

Correa, M., Rivas, B. \& Somma, V. (1993). Drugs and AIDS in Uruguay. Poster (PO-D08-3640) presented at the IX International Conference on AIDS, Berlin.

DES JARLA IS, D.C. (1998). Intoxications, intentions, and disease prevention [Editorial]. Sexually Transmitted Diseases, 24, pp. 320-21.

Des Jarlais, D.C., Friedman, S.R. \& Hopkins, W. (1985). Risk reduction for the acquired immunodeficiency syndrome among intravenous drug users. Annals of Internal Medicine, 103, pp. 75559.

Des Jarlais, D.C., Casriel, C., Friedman, S.R. \& Rosenblum, A. (1992). AidS and the transition to illicit drug injection. Results of a randomized trial prevention program. British Journal of Addictions, 87 , pp. 493-98.

Des Jarlais, D.C. \& Friedman, S.R. (1993). AIDS, injecting drug use and harm reduction. In N. Heather, A. Wodak, E. Nadelmann \& P. O'Hare (Eds), Psychoactive Drugs E Harm Reduction, (pp. 297-309). London: Whurr Publishers.

Des Jarlais, D.C., Stimson, G. \& Hagan, H. et al., (1996). Emerging infectious diseases and the injection of illicit psychoactive drugs. Current Issues in Public Health, 2, pp. 1320-27.

Dias, M.B.S., Lima, J.N. \& ABreu, W.B. et al., (1989). Follow-up of groups at risk for HIV infection. Poster [T.G.P.14] presented at the V International Conference on AIDS, Montreal.

EdLin, B.R., IrWin, K.L. \& FARUque, S. et al. (1994). Intersecting epidemics-crack cocaine and HIV infection among inner-city young adults. The Multicenter Crack Cocaine and HIV Infection Study Team. New England Journal of Medicine, 331, pp. 1422-27.

Fay, O., Biglione, J. \& Fernández, E. et al. (1989). HiV in various risk communities in the north east of Argentina. Poster (M.G.P.29) presented at the V International Conference on AIDS, Montreal.

FAy, O., TABorda, A. \& FERnÁndeZ, E. et al. (1991). HIV seroprevalence among different communities in Argentina after four years of surveillance. Poster (M.C.3263) presented at the VII International Conference on AIDS, Florence.

Ferreira, A., Grandi, J. \& Fernandes, M. et al. (1989). Epidemiological findings of HiV infection among women in São Paulo, Brazil. Poster [Th.G.P.26] presented at the V International Conference on AIDS, Montreal.

Fonseca, M.G.P. \& CAstilho, E.A. (1997). Os casos de aids entre usuários de drogas injetáveis. Brasil, 1980-1997 [AIDS cases among IDUs in Brazil, 1980-1997]. Boletim Epidemiológico, X, pp.6-14.

FRIEDMAN, S.R. (1993). AIDS as a sociohistorical phenomenon. In The Social and Behavioral Aspects of AIDS. Advances in Medical Sociology (Vol. 3, pp. 19-36). New York: JAI Press.

Friedman, S.R., FriedmanN, P. \& Telles, P.R. et al. (1998). New injectors and HIV-1 risk. In G. Stimson, D.C. Des Jarlais \& A. Ball (Eds), Drug Injecting and HIV Infection: global dimensions and local responses, (pp. 76-90). London: UCL Press. 
Garfein, R.S., Vlahov, D., Galai, N., Doherty, M.C. \& Nelson, K.E. (1996). Viral infections in short-term injection drug users: the prevalence of the hepatitis C, hepatitis B, human immunodeficiency virus, and human T-lymphotropic viruses. American Journal of Public Health, 86, pp. 655-61.

Gianna, M.C., Munhoz, R. \& Grangeiro, A. et al. (1992). HIV soroprevalence in malaria outbreak related to the IVDU. Poster [PoC 4253] presented at the VIII International Conference on AIDS, Amsterdam.

Giffin, K. \& Lowndes, C.M. Gender, sexuality, and the prevention of sexually transmissible diseases: a Brazilian study of clinical practice. Social Science and Medicine, pp. 283-292.

Gomez, M.P., BAIN, R.M. \& MAJOR, C. et al. (1996). Characteristics of HIV-infected pregnant women in the Bahamas. Journal of Acquired Immune Deficiency Syndromes and Human Retrovirology, 12, pp. 400-05.

Gonçalves, V.L.C., Dos Anjos, R.M.P., Ramos, T.F. \& Gomes, C.O.M. (1989). Sorocaba ambulatory AIDS experience with prostitutes. Poster [D.693] presented at the V International Conference on AIDS, Montreal.

Grangeiro, A. (1994). O perfil sócio-econômico da AIDS no Brasil [The socio-economic profile of AIDS in Brazil]. In R. Parker, C. Bastos, J. Galvão \& J.S. Pedrosa (Eds), A Aids no Brasil, (pp. 91-125). Rio de Janeiro: ABIA/UERJ \& Relume-Dumará.

Gupta, S., Anderson, R.M. \& MAy, R.M. (1989). Networks of sexual contacts: implications for the pattern of spread of HIV. AIDS, 3, pp. 807-17.

Hamers, F.F., Batter, V. \& Downs, A.M. et al., (1997). The HIV epidemic associated with injecting drug use in Europe: geographic and time trends. AIDS, 11, pp. 1365-74.

Hyppolite, P.R. \& PAPE, J.W. (1995). Infección por VIH y tuberculosis en Haití [HIV infection and tuberculosis in Haiti]. Boletín de la Oficina Sanitaria Panamericana, 118, pp. 161-69.

INCHAURRAGA, S. (1997). Drogadiccion y SIDA [Drugabuse and AIDS]. In S. INCHAuRRAGA (Ed.), El SIDA en la Cultura: Problemáticas a Fines de Siglo. Rosario: Homo Sapiens Ediciones, pp. 85-90.

Inciardi, J.A., Surratt, H. \& Telles, P. et al., (1996). Risks for HIV-1 infection and seropositivity rates among cocaine users in Rio de Janeiro, Brazil. Poster [Th.C.425] presented at the XI International Conference on AIDS, Vancouver.

Ivo-dos-Santos, J., Couto-Fernandez, J.C. \& Santana, A.J. et al., (1991). Prevalence of HiV antibodies in selected groups of a Brazilian city with African sociodemographic characteristics. Journal of Acquired Immune Deficiency Syndromes and Human Retrovirology 4, pp. 448-49.

Jiménez, A.H.G. (1995). Tuberculosis y sida en el Paraguay [Tuberculosis and AIDS in Paraguay]. Boletín de la Oficina Sanitaria Panamericana,118, pp. 249-53.

Johnson, W.A. \& Ouellet, L.J. (1996). The injection of crack cocaine among Chicago drug users. American Journal of Public Health, 86, p. 266 [letter].

Jose, B., Friedman, S.R. \& Neaigus, A. et al., (1993). Syringe-mediated drug-sharing (backloading): a new risk factor for HIV among injecting drug users. AIDS, 7, pp. 1653-60.

Kalichman, A. (1993). AIDS and intravenous drug use (IVDU) in Brazil. In M.G. Monteiro \& J.A. INCIARDi (Eds), Brasil-United States Binational Research (pp. 49-61). São Paulo: CEBRID.

KleE, H. (1992). Sexual risk among amphetamine misusers: prospects for change. In P. AgGLETON, P. Davies \& G. HART (Eds), AIDS: Rights, Risk and Reason (pp.77-84). London/W ashington: The Falmer Press.

Koester, S., Bоoth, R.E. \& ZhanG, Y. (1996). The prevalence of additional injection-related HIV risk behaviors among injection drug users. Journal of Acquired Im mune Deficiency Syndromes and Human Retrovirology, 12, pp. 202-07.

Laranjeira, R., Ratto, L. \& Dunn, J. (1997). Heroína: a próxima epidemia de drogas no Brasil? [Heroin: the next illicit drugs epidemic in Brazil?]. Jornal Brasileiro de Psiquiatria, 46, pp. 5-7.

Leite, E.A., Hamerschlak, N. \& Bellucci, S.B.B. et al., (1989). HIV infection in I.V. drug abusers. Poster [D.709] presented at the V International Conference on AIDS, Montreal.

Lima, E.S., FriedmAn, S.R. \& BAstos, F.I. et al., (1994). Risk factors for HIV infection among cocaine injectors in Rio de Janeiro, Brazil. Addiction, 89, pp. 689-98.

Lima, M.P.S., Rocha, M.D.C. \& Tanibata, P.R. et al., (1989). Profile of users of the drug IV in the periphery of Campinas. Poster [D.604] presented at the V International Conference on AIDS, Montreal.

Llosa, T. (1994). The standard low dose of oral cocaine used for treatment of cocaine dependence. Substance Abuse, 15, pp. 215-20.

López, A. (1997). El nuevo mapa de la pobreza porteña. Muertes por SIDA, viviendas deficitarias y marginacion escolar deficiente [The new map of the poverty in Buenos Aires, housing shortage and low scholar attainment]. Cuaderno IDEP, 52, pp. 3-35. 
Low, N., Egger, M. \& Gorter, A. et al., (1993). AIDS in Nicaragua: epidemiological, political, and sociocultural perspectives. International Journal of Health Services, 23, pp. 685-702.

Marques, F. \& Doneda, D. (1998). A política brasileira de redução de danos à saúde pelo uso indevido de drogas: diretrizes e seus desdobramentos nos estados e municípios [The Brazilian policy on the reduction of drug-related harm: guidelines and its implementation in Brazilian states and municipalities]. In F.I. Bastos \& F.C. Mesquita (Eds), Troca de Seringas, Drogase AID S: Ciência, Debate e Saúde Pública (pp. 137-152). Brasília: Ministério da Saúde/UNDCP.

McCarthy, M.C., Wignall, F.S. \& SAnChez, J. et al., (1996). The epidemiology of HIV-1 infection in Peru, 1986-1990. AIDS, 10, pp. 1141-45.

McKeganey, N. \& BARnARD, M. (1992). AIDS, Drugs and Sexual risk. Lives in the Balance. Buckingham / Philadelphia: Open University Press.

Mendes, N.F., Dines, I. \& Peixinho, Z.F. et al., (1988). HIV-1 antibodies in Brazilian intravenous drug-addicts. Poster [5086] presented at the IV International Conference on AIDS, Stockholm.

Miguez, M.J., Page, B. \& Baum, M.K. (1997). Illegal drug use and HIV-1 infection in Colimbia. The Lancet, 350, p. 1635 [letter].

Míguez, H.A., Pecci, M.C. \& Carrizosa, A. (1992). Epidemiología de abuso del alcohol y las drogas en Paraguay [Epidemiology of drug and alcohol abuse in Paraguay]. Acta Psiquiátrica y Psiocológica de la América Latina, 38, pp. 19-29.

Minayo, M.C., Deslandes, S.F. \& Souza, E.R. et al., (1998). Avaliação das atividade de redução de danos no Brasil [Evaluation of Brazilian harm-reduction projects]. FIOCRUZ/Brazilian Ministry of Health, Final Report.

Montoya, I.D. \& AtKInson, J.S. (1996). Determinants of HIV seroprevalence rates among sites participating in a community-based study of drug users. Journal of Acquired Immune Deficiency Syndromes and Human Retrovirology,13, pp. 169-76.

Muchinik, G., FAy, O. \& CAHn, P. et al., (1988). HIV seropositivity in high-risk groups in Argentina: Future impact on heterosexual transmission. Poster (5062) presented at the IV International Conference on AIDS, Stockholm.

Murillo, J. \& Castro, K.G. (1994). HIV infection and AIDS in Latin America. Epidemiologic features and clinical manifestations. Infectious Disease Clinics of North America, 8, pp. 1-11.

Negrete, P. (1981). La región andina de América del Sur: el hábito local de mascar coca en las zonas rurales y fumar pasta de coca en las ciudades [The Andean region in South America: the local habit of coca leaf chewing in the countryside and smoke raw coca base in the cities]. In G. EDWARDS \& A. Arif (Eds), Los Problemas de la Droga en el Contexto Sociocultural, (pp. 65-73). Geneva: WHO.

PeñA. R.T., Fiol, J.J. \& Corzo, L.C. et al., (1995). La infección por el VIH y tuberculosis en Cuba [HIV infection and tuberculosis in Cuba]. Boletín de la Oficina Sanitaria Panamericana,119, pp. 67-73.

Pérez-Gómez, A. (1996). Drug injecting in Bogota, Colombia. WHO Drug Injecting Project Planning Meeting Phase II. Geneva: PSA/WHO.

Raffaelli, M., Campos, R. \& Merritt, A.P. et al., (1993). Sexual practices and attitudes of street children youth in Belo Horizonte, Brazil. Social Science and Medicine, 37, pp.661-70.

Ramos, T.F., Gonçalves, V.L.C. \& Dos Anjos, R.M.P. et al., (1989). Sorocaba ambulatory external service experience related to AIDS and users of injectable drugs. Poster (D.584) presented at the $\mathrm{V}$ International Conference on AIDS, Montreal.

Robles, R.R., Marrero, C.A., Reyes, J.C. et al., (1998). Risk behaviors, HIV seropositivity, and tuberculosis infection in injecting drug users who operate shooting galleries in Puerto Rico. Journal of Acquired Immune Deficiency Syndromes and Human Retrovirology,17, pp. 477-83.

Rubio, L., Fay, O. \& TABorda, M. et al., (1990). HIV seroprevalence in Latin America and the Caribbean. Poster (F.C.578) presented at the VI International Conference on AIDS, California.

Scheerer, S. \& Vogt, I. (1989). Drogen und Drogenpolitik. Frankfurt/New York: Campus Verlag.

Seidman, S.N., Sterk-Elfson, C. \& Aral, S.O. (1994). High-risk sexual behavior among drug-using men. Sexually Transmitted Diseases, 21, pp. 173-80.

Shafer, M.A., Hilton, J.F. \& Ekstrand, M. et al., (1993). Relationship between drug use and sexual behaviors and the occurrence of sexually transmitted diseases among high-risk male youth. Sexually Transmitted Diseases, 20, pp. 307-13.

Stimson, G.V. (1995). AIDS and injecting drug use in the United Kingdom, 1987-1993: the policy response and the prevention of the epidemic. Social Science and Medicine, 41, pp. 699-716.

Strang, J., Des Jarlais, D.C., Griffiths, P. \& Gossop, M. (1992). The study of transitions in the route of drug use: the route from one route to another. British Journal of Addictions, 87, pp. 473-84.

Strathdee, A.S., Patrick, D.M. \& Archibald, C.P. et al., (1997a). Social determinants predict needle-sharing behaviour among injecting drug users in Vancouver, Canada, Addiction, 92, pp. 1339-47. 
Strathdee, A.S., Patrick, D.M. \& Currie, S. et al., (1997b). Needle exchange is not enough: lessons from the Vancouver Injection Drug Use Study. AIDS, 11, pp. F59-65.

Strathdee, A.S., Palepu, A. \& Cornelisse, P.G.A. et al., (1998a). Barriers to use of free antiretrovirals therapy in injecting drug users. Journal of the American Medical Association, 280, pp. 547-49.

Strathdee, A.S., van Ameijden, E. \& Mesquita, F. et al., (1998b). Can HiV epidemics among injection drug users be prevented? AIDS, suppl. A, pp. S71-79.

Susser, M. (1994). The logic in ecological. In A. Nicolosi (Ed.), HIV Epidemiology:models and methods. New York: Raven Press, pp. 161-174.

SzWARCWALD, C.L. \& BASTOS, F.I. (1998). Spatiotemporal model: an application to the AIDS epidemic in São Paulo, Brazil. In L. Gierl, A.D. Cliff, A.J. Valleron, P. Farrington \& M. Bull (Eds), Geomed '97 (pp. 43-53). Stuttgart/Leipzig: B.G. Teubner.

Szwarcwald, C.L., Bastos, F.I., Barcellos, C. \& Pina, M.F. (1998a). The geography of health indicators in Rio de Janeiro: two cities in one. Paper [303] presented at the International Health Geographics Conference, Baltimore, Maryland.

SzwarCw Ald, C.L., Bastos, F.I. \& CAstilho,E.A. (1998b). The dynamic of the AIDS epidemic in Brazil: a spatio-time analysis in the period 1987-1995. Brazilian Journal of Infectious Diseases, 2, pp. 175-186.

Szwarcwald, C.L., Bastos, F.I. \& Gravato, N. et al., (1988c). The relationship of illicit drug consumption to HIV-infection among commercial sex workers (CSWs) in the city of Santos, São Paulo, Brazil. The International Journal of Drug Policy, 9, pp. 427-436.

Taylor, A., Goldberg, D. \& Emslie, J. et al., (1995). Outbreak of HiV infection in a Scottish prison. British Medical Journal, 310, pp. 289-92.

TeIXeIRA, P.R. (1997). La interacción VIH/SIDA y drogas en los países del Cono Sur [The intersection between HIV/AIDS and drug abuse in the Southern Cone]. Background paper prepared for the Meeting of the Project Drugabuse and AIDS in the Southern Cone, Montevideo, Uruguay.

Telles, P.R. \& Bastos, F. pelo Projeto Brasil (1995). O contexto do uso de drogas em cinco cidades brasileiras [The drug scene in five different Brazilian cities]. Boletim ABIA, 27, pp. 10-12.

Telles, P.R., Bastos, F.I. \& GuYdish, J. et al., (1997). Risk behaviors and HiV seroprevalence among IDUs in Rio de Janeiro, Brazil. AIDS, 11, pp. S35-44.

Turienzo, G.T., Burattini, M.N. \& Massad, E. (1997). Social-demographic patterns and trends in risky behaviors of IDUs in the City of Santos, São Paulo, Brazil: a comparison between 1992 and 1994. Poster presented at the VIII International Conference on the Reduction of Drug Related Harm, Paris.

Valdespino-Gómez, J.L., García-García, M.L. \& Río-Zolezzi, M.C. et al., (1995). Epidemiología del SIDA/VIH en México; de 1983 a marzo de 1995 [The epidemiology of HIV/AIDS in Mexico, 1983-1995]. Salud Pública de México, 37, pp. 556-71.

Van Ameijden, E.J.C., van den Hoek, J.A.R. \& Hartgers, C. et al., (1994). Risk factors for the transition from noninjection to injection drug use and accompanying AIDS risk behavior in a cohort of drug users. American Journal of Epidemiology,139, pp. 1153-63.

Victora, C.G., Huttly, S.R., Fuchs, S.C. \& Olinto, M.T.A. (1997). The role of conceptual framew orks in epidemiological analysis: a hierarchical approach. International Journal of Epidemiology, 26, pp. 224-27.

Wallace, R. (1993). Social disintegration and the spread of AIDS. Social Science and Medicine, 37, pp. 887-96.

WEISSENBACHER et al., (1988).

Wodak, A., Fisher, R. \& Crofts, N. (1993). An evolving public health crisis: HIV infection among injecting drug users in developing countries. In: N. Heather, A. Wodak, E. NAdelmanN \& P. O'Hare (Eds), Psychoactive Drugs \& Harm Reduction (pp. 280-96) London: Whurr Publishers.

WhO International Collaborative Group (1994). Multi-city Study on Drug Injecting and Risk of HIV Infection. Geneva: WHO.

Yañez, A., BAchelet, M. \& VAlenzuela, M.T. et al., (1995). La infección por VIH y sus consecuencias para la endemia tuberculosa en Chile [HIV infection and its impact upon tuberculosis in Chile]. Boletín de la Oficina Sanitaria Panamericana,119, pp. 167-78. 